\title{
EFFECT OF SHORT-TERM ZINC SUPPLEMENTATION ON ZINC AND SELENIUM TISSUE DISTRIBUTION AND SERUM ANTIOXIDANT ENZYMES
}

\author{
Andrey A. Skalny ${ }^{1,2}$, Alexey A. Tinkov ${ }^{2,3}, 4$, Yulia S. Medvedeva ${ }^{5}$, Irina B. Alchinova ${ }^{5}$, \\ Mikhail Y. Karganov ${ }^{5}$, Anatoly V. Skalny ${ }^{2,3,5}$, Alexandr A. Nikonorov ${ }^{4}$ \\ ${ }^{1}$ Federal State Scientific Institution Institute of Toxicology, Federal Medico-Biological Agency \\ Bekhtereva 1, St. Petersburg 192019, Russia \\ ${ }^{2}$ Russian Society of Trace Elements in Medicine, ANO Centre for Biotic Medicine \\ Zemlyanoy Val 46, Moscow 105064, Russia \\ ${ }^{3}$ Laboratory of Biotechnology and Applied Bioelementology, Yaroslavl State University \\ Sovetskaya 14, Yaroslavl 150000, Russia \\ ${ }^{4}$ Department of Biochemistry, Orenburg State Medical University \\ Sovetskaya 6, Orenburg 460000, Russia \\ ${ }^{5}$ Laboratory of Physicochemical and Ecological Pathophysiology, Institute of General Pathology and Pathophysiology \\ Baltiyskaya 8, Moscow 125315, Russia \\ ${ }^{6}$ Institute of Bioelementology (Russian Satellite Centre of Trace Element - Institute for UNESCO), Orenburg State University \\ Pobedy Av. 13, Orenburg 460352, Russia
}

\begin{abstract}
Background. A significant association between $\mathrm{Zn}$ and Se homeostasis exists. At the same time, data on the influence of zinc supplementation on selenium distribution in organs and tissues seem to be absent. Therefore, the primary objective of the current study is to investigate the influence of zinc asparaginate supplementation on zinc and selenium distribution and serum superoxide dismutase (SOD) and glutathione peroxidase (GPx) activity in Wistar rats.

Material and methods. 36 rats were used in the experiment. The duration of the experiment was 7 and 14 days in the first and second series, respectively. The rats in Group I were used as the control ones. Animals in Groups II and III daily obtained zinc asparaginate (ZnA) in the doses of 5 and $15 \mathrm{mg} / \mathrm{kg}$ weight, respectively. Zinc and selenium content in liver, kidneys, heart, muscle, serum and hair was assessed using inductively coupled plasma mass spectrometry. Serum SOD and GPx activity was analysed spectrophotometrically using Randox kits.

Results. Intragastric administration of zinc asparaginate significantly increased liver, kidney, and serum zinc content without affecting skeletal and cardiac muscle levels. Zinc supplementation also stimulated selenium retention in the rats' organs. Moreover, a significant positive correlation between zinc and selenium content was observed. Finally, zinc asparaginate treatment has been shown to modulate serum GPx but not SOD activity.

Conclusion. The obtained data indicate that zinc-induced increase in GPx activity may be mediated through modulation of selenium status. However, future studies are required to estimate the exact mechanisms of zinc and selenium interplay.
\end{abstract}

Key words: zinc asparaginate, selenium, superoxide dismutase, glutathione peroxidase 


\section{INTRODUCTION}

Zinc and selenium are essential trace elements due to their cofactor function in a number of enzymatic systems (Kaim et al., 2013). In particular, these metals are cofactors for $\mathrm{Cu}, \mathrm{Zn}$-superoxide dismutase (SOD) and glutathione peroxidase (GPx) that play a significant role in maintenance of redox homeostasis (Bettger, 1993). Zinc and selenium deficiency is characterised by various clinical signs due to the participation of trace elements in numerous metabolic pathways (Lee, 2012). The incidence of poor zinc and selenium status is high in certain territories (Diplock, 1993; Prasad, 2003). It is notable that combined zinc and selenium deficiency is frequently observed in a number of pathologic states (Barretto et al., 2008; Çavdar et al., 2009; Khalili et al., 2008) as well as in relatively healthy population (De Jong et al., 2001). Such a fact indicates a significant association between $\mathrm{Zn}$ and Se homeostasis. Moreover, a number of fundamental studies have investigated a chemical basis of this association (Blessing et al., 2004; Feroci et al., 2005). Earlier studies have indicated the possibility of mutual influence of zinc and selenium in the case of supplementation. In particular, it has been shown that zinc supplementation in dialysis patients increases serum selenium concentration (Guo et al., 2013). A simultaneous administration of selenium and zinc resulted in enhanced trace elements retention in organs and tissues (Chmielnicka et al., 1988). Moreover, selenium supplementation has also been shown to increase tissue selenium in animals fed both zinc-adequate and zinc-deficient diet (Fatmi et al., 2013). At the same time, data on the influence of zinc supplementation on selenium distribution in organs and tissues seem to be absent. Therefore, the primary objective of the current study is to investigate the influence of zinc asparaginate supplementation on zinc and selenium distribution and serum SOD and GPx activity in Wistar rats.

\section{MATERIAL AND METHODS}

36 male Wistar rats were used in the experiment. The research was approved by the Local Ethics Committee. The animals have been acclimatized to the laboratory conditions for two weeks prior to the experiment. The animals were maintained in a laboratory on a regular 12:12 h light-dark cycle (lights on at 8.00 a.m.) and fed a standard diet ad libitum. Granulated chow PK-120 ("Laboratorkorm" Ltd., Moscow, Russia) containing $307 \mathrm{kcal} / 100 \mathrm{~g}(20 \%$ protein, $70 \%$ carbohydrate, $10 \%$ fat) was used as a standard diet. Zinc and selenium content in the rat chow was $78.6 \pm 5.1$ and $0.17 \pm 0.04$ $\mu \mathrm{g} / \mathrm{g}$, respectively. The animals received pure drinking water with general mineralization $<250 \mathrm{mg} / \mathrm{l}$.

Two series of experiments were performed. The duration of the experiment was 7 and 14 days in the first and second series, respectively. The rats in Group I were used as the control ones. Animals in Groups II and III daily obtained zinc asparaginate ( $\mathrm{ZnA})$ $\mathrm{Zn}\left(\mathrm{C}_{4} \mathrm{NO}_{4} \mathrm{H}_{6}\right)_{2} \cdot \mathrm{Zn}(\mathrm{OH})_{2}$ in the doses of $5(\mathrm{ZnA} 5)$ and $15 \mathrm{mg} / \mathrm{kg}$ weight (ZnA15), respectively. Zinc asparaginate in starch was given by intragastric gavage (at 10.00 a.m.) using silicone flexible catheters.

Blood was collected via venesection of the jugular vein with subsequent separation of serum. Rats' liver, kidneys, heart, and muscles (m. gastrocnemius) were collected at the end of the experiment. The organs and tissues were separated from connective tissue and rinsed with ice-cold physiological saline. Hair was collected from the cranial part of the spine. The obtained samples were used for subsequent chemical analysis.

Hair samples were washed with acetone and then rinsed twice with deionized water in order to remove possible mechanical contamination (Zhao et al., 2012). Afterwards, the samples were dried on air at $60^{\circ} \mathrm{C}$. Blood samples were added with an acidified $(\mathrm{pH}=2.0)$ diluent $(1: 15 \mathrm{v} / \mathrm{v})$. The diluent consisted of 1\% 1-butanol (Merck KGaA, 64271 Darmstadt, Germany), 0.1\% Triton X-100 (Sigma-Aldrich, Co., St. Louis, MO 63103 USA), and $0.07 \%$ HNO3 (Sigma-Aldrich, Co., St. Louis, MO 63103 USA) in distilled deionized water. All samples were subjected to microwave decomposition. Briefly, $50 \mathrm{mg}$ of hair, organs, tissues and serum were introduced into Teflon tubes with subsequent addition of concentrated nitric acid. The samples were digested in a Berghof speedwave four system for 20 minutes at $180^{\circ} \mathrm{C}$. The obtained probes were analyzed for zinc and selenium content by inductively coupled plasma mass spectrometry using NexION 300D (PerkinElmer Inc., Shelton, CT 06484, USA) equipped with ESI SC-2 DX4 (Elemental Scientific Inc., Omaha, NE 68122, USA) autosampler. The use of Dynamic Reaction Cell technology allows to minimize the majority of interferences without the loos of sensitivity. 
The system was prepared in accordance with the manufacturer's recommendations. Calibration was performed using $0.5,5,10$, and $50 \mu \mathrm{g} / 1$ solutions of zinc and selenium prepared from Universal Data Acquisition Standards Kit (PerkinElmer Inc., Shelton, CT 06484, USA) by addition of distilled deionized water acidified with $1 \%$ nitric acid. Internal standardization was performed using yttrium $\left({ }^{89} \mathrm{Y}\right)$ isotope Yttrium (Y) Pure Single-Element Standard (PerkinElmer Inc., Shelton, CT 06484, USA) on a matrix containing $8 \%$ 1-butanol (Merck KGaA, 64271 Darmstadt, Germany), $0.8 \%$ Triton X-100 (Sigma-Aldrich, Co., St. Louis, MO 63103 USA), $0.02 \%$ tetramethylammonium hydroxide (Alfa-Aesar, Ward Hill, MA 01835 USA), and $0.02 \%$ ethylenediaminetetraacetic acid (SigmaAldrich, Co., St. Louis, MO 63103 USA). Reference materials were additionally used for quality control. Standard GBW09101 hair sample (Shanghai Institute of Nuclear Research, Shanghai, China) was used as a reference material during hair trace element analysis. Laboratory control of serum analysis was performed using ClinCheck Plasma Control, lot 129, levels 1 and 2 (RECIPE Chemicals + Instruments GmbH, Germany).

Blood serum was also used for estimation of SOD and GPx activity using Randox kits (Randox Laboratories Ltd., Crumlin, United Kingdom) on an automated biochemical analyser Tokyo Boeki (Tokyo Boeki Machinery Ltd., Tokyo, Japan).

The obtained data are expressed as mean values and the respective standard deviations (mean $\pm \mathrm{SD}$ ). One-way ANOVA was used for data processing in order to reveal significant influence of zinc supplementation on the studied parameters ( $p$ trend of the overall tendency). Fisher's Least Significant Difference test was used for group mean comparisons. Correlation analysis was performed using Spearman's correlation coefficient. The significance level for all statistical analyses was set as $p<0.05$. Statistical treatment of the data obtained was performed using Statistica 10 (StatSoft Inc., Tulsa, Oklahoma, USA).

\section{RESULTS}

The influence of zinc asparaginate supplementation on zinc content in organs and tissues

The obtained data demonstrated an increase in zinc content as a result of intragastric gavage of zinc asparaginate (Table 1). In particular, administration of 5 and
$15 \mathrm{mg} / \mathrm{kg} \mathrm{ZnA} \mathrm{for} 7$ days resulted in 11 and $23 \%$ elevation of liver zinc content in comparison to the control values. Similar effect was observed after 14-days treatment. Liver zinc levels in rats obtaining $15 \mathrm{mg} / \mathrm{kg}$ ZnA significantly exceeded the respective values obtained for the first and second groups by 19 and $15 \%$.

Kidney zinc content was also affected by zinc supplementation. 7-days administration of $15 \mathrm{mg} / \mathrm{kg} \mathrm{ZnA}$ resulted in a significant elevation of kidney $\mathrm{Zn}$ levels by 6 and $12 \%$ as compared to the I and II Group values, respectively. Treatment with $15 \mathrm{mg} / \mathrm{kg}$ zinc asparaginate for 14 days was associated with a significant 19 and $9 \%$ increase in kidney zinc content in comparison to the respective values in the control and ZnA5 groups.

M. gastrocnemius zinc content was not significantly affected by administration of zinc asparaginate in the experimental groups. Moreover, the overall tendency was not significant.

Zinc treatment for 7 days was accompanied by a relative decrease in heart zinc content. Oppositely, administration of $\mathrm{ZnA}$ for 14 days led to an increase in heart zinc values. However, both tendencies were not significant.

Intragastric gavage of zinc significantly affected serum metal concentration. In particular, treatment with 5 and $15 \mathrm{mg} / \mathrm{kg}$ zinc asparaginate for 7 and 14 days resulted in a respective significant 35 and $45 \%$, and 55 and $107 \%$ increase in serum $\mathrm{Zn}$ when compared to the control values.

Zinc asparaginate supplementation for 7 days did not result in any significant changes in rats' hair zinc content. At the same time, treatment with 5 and $15 \mathrm{mg} / \mathrm{kg}$ $\mathrm{ZnA}$ for 14 days increased hair zinc content by 10 and $12 \%$ in comparison to the control level.

It is notable that no significant differences in organs zinc content between the respective groups of animals treated for 7 and 14 days were observed. At the same time, the overall tendency to treatment-induced increase in zinc content in liver, kidneys and serum was more expressed after 14 days of treatment in accordance with one-way ANOVA results.

\section{The influence of zinc asparaginate supplementation on selenium content in organs and tissues}

Along with increased zinc content, treatment with zinc asparaginate significantly affected selenium distribution in organs (Table 1). 
Skalny, A. A., Tinkov, A. A., Medvedeva, Y. S., Alchinova, I. B., Karganov, M. Y., Skalny, A. V., Nikonorov, A. A. (2015). Effect of shortterm zinc supplementation on zinc and selenium tissue distribution and serum antioxidant enzymes. Acta Sci. Pol. Technol. Aliment., 14(3), 269-276. DOI: 10.17306/J.AFS.2015.3.28

Table 1. Influence of zinc supplementation on $\mathrm{Zn}$ and Se distribution in organism

\begin{tabular}{|c|c|c|c|c|}
\hline Parameter & Control (I) & ZnA5 (II) & ZnA15 (III) & $p$ trend \\
\hline \multicolumn{5}{|c|}{7 days } \\
\hline Zn liver & $28.75 \pm 3.74$ & $31.82 \pm 2.15$ & $35.44 \pm 4.93^{\mathrm{a}}$ & $0.026^{*}$ \\
\hline Zn kidney & $18.88 \pm 1.15$ & $18.02 \pm 0.72$ & $20.11 \pm 1.37^{\mathrm{a}, \mathrm{b}}$ & $0.017^{*}$ \\
\hline Zn muscle & $8.82 \pm 2,02$ & $8.70 \pm 1.92$ & $10.46 \pm 3,16$ & 0.414 \\
\hline Zn heart & $17.13 \pm 0.77$ & $16.77 \pm 1.55$ & $16.13 \pm 0.61$ & 0.282 \\
\hline Zn serum & $1.15 \pm 0.27$ & $1.55 \pm 0.22^{\mathrm{a}}$ & $1.67 \pm 0.28^{\mathrm{a}}$ & $0.021 *$ \\
\hline Zn hair & $150.50 \pm 8.80$ & $151.17 \pm 6.59$ & $144.83 \pm 9.70$ & 0.386 \\
\hline Se liver & $0.63 \pm 0.09$ & $0.58 \pm 0.05$ & $0.80 \pm 0.07^{\mathrm{a}, \mathrm{b}}$ & $<0.001^{*}$ \\
\hline Se kidney & $1.25 \pm 0.12$ & $1.04 \pm 0.20^{\mathrm{a}}$ & $1.27 \pm 0.17^{\mathrm{b}}$ & 0.057 \\
\hline Se muscle & $0.12 \pm 0.01$ & $0.04 \pm 0.01^{\mathrm{a}}$ & $0.14 \pm 0.02^{\mathrm{a}, \mathrm{b}}$ & $<0.001^{*}$ \\
\hline Se heart & $0.31 \pm 0.03$ & $0.22 \pm 0.03^{\mathrm{a}}$ & $0.33 \pm 0.03^{\mathrm{b}}$ & $<0.001^{*}$ \\
\hline Se serum & $0.45 \pm 0.04$ & $0.43 \pm 0.06^{\mathrm{c}}$ & $0.50 \pm 0.03^{b}$ & 0.054 \\
\hline Se hair & $0.23 \pm 0.01$ & $0.23 \pm 0.03$ & $0.26 \pm 0.02^{\mathrm{b}}$ & 0.087 \\
\hline \multicolumn{5}{|c|}{14 days } \\
\hline Zn liver & $28.72 \pm 2.24$ & $29.77 \pm 1.66$ & $34.30 \pm 3.14^{\mathrm{a}, \mathrm{b}}$ & $0.002 *$ \\
\hline Zn kidney & $17.32 \pm 1.58$ & $18.86 \pm 0.97$ & $20.54 \pm 1.81^{\mathrm{a}, \mathrm{b}}$ & $0.007 *$ \\
\hline Zn muscle & $10.67 \pm 1,39$ & $11.94 \pm 3,62$ & $12.70 \pm 6,81$ & 0.849 \\
\hline Zn heart & $15.99 \pm 0.69$ & $16.46 \pm 0.59$ & $16.92 \pm 1.94^{\mathrm{a}}$ & 0.446 \\
\hline Zn serum & $0.91 \pm 0.14$ & $1.41 \pm 0.30^{\mathrm{a}}$ & $1.88 \pm 0.30^{\mathrm{a}, \mathrm{b}}$ & $<0.001^{*}$ \\
\hline Zn hair & $124.78 \pm 11.88$ & $136.04 \pm 5.49$ & $139.89 \pm 13.83^{\mathrm{a}}$ & 0.077 \\
\hline Se liver & $0.60 \pm 0.05$ & $0.64 \pm 0.08$ & $0.71 \pm 0.04^{\mathrm{a}, \mathrm{c}}$ & $0.035^{*}$ \\
\hline Se kidney & $1.16 \pm 0.08$ & $1.14 \pm 0.11$ & $1.07 \pm 0.13^{\mathrm{c}}$ & 0.330 \\
\hline Se muscle & $0.25 \pm 0.05$ & $0.32 \pm 0.04^{\mathrm{a}}$ & $0.16 \pm 0.05^{\mathrm{a}, \mathrm{b}}$ & $<0.001 *$ \\
\hline Se heart & $0.29 \pm 0.04$ & $0.32 \pm 0.02^{\mathrm{c}}$ & $0.30 \pm 0.04$ & 0.284 \\
\hline Se serum & $0.43 \pm 0.03$ & $0.41 \pm 0.05$ & $0.43 \pm 0.04$ & 0.469 \\
\hline Se hair & $0.28 \pm 0.03$ & $0.30 \pm 0.03$ & $0.33 \pm 0.03^{\mathrm{a}, \mathrm{b}}$ & $0.028^{*}$ \\
\hline
\end{tabular}

Values are expressed as mean $\pm \mathrm{SD}$.

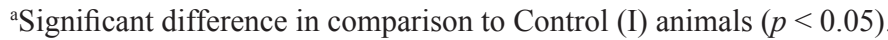

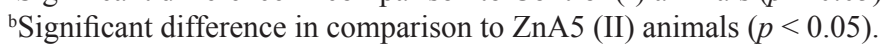

'Significant difference in comparison to the respective group treated for 7 days.

$* p$ trend is significant at $p$ values $<0.05$.

In particular, supplementation with $15 \mathrm{mg} / \mathrm{kg} \mathrm{ZnA}$ for 7 and 14 days resulted in a significant 28 and $17 \%$ increase in liver selenium content in comparison to the control group values. However, zinc-induced selenium deposition in liver was less expressed after 14 days of treatment.
It is notable that treatment with $5 \mathrm{mg} / \mathrm{kg}$ zinc asparaginate decreased selenium content in the studied organs. In particular, rats from Group II were characterised by a 16,70 , and $29 \%$ decrease in kidney, muscle, and heart content as compared to the control values, respectively. At the same time, intragastric 
administration of $15 \mathrm{mg} / \mathrm{kg} \mathrm{ZnA} \mathrm{resulted} \mathrm{in} \mathrm{a} 28$ and $20 \%$ elevation of liver and muscle selenium content in comparison to the respective control values. Moreover, the obtained values of selenium content in organs and tissues of rats exposed to $15 \mathrm{mg} / \mathrm{kg} \mathrm{ZnA}$ significantly exceeded the respective parameters in the Group II (ZnA5). It has been noted that the overall tendency to zinc-induced changes in selenium content in liver, heart, and muscle was significant in accordance with one-way ANOVA. Such tendency in the case of kidney and serum selenium levels was fairly significant.

The reverse character of changes in serum and muscle selenium levels was observed after zinc treatment for 14 days. In particular, supplementation of $5 \mathrm{mg} / \mathrm{kg}$ zinc asparaginate resulted in increased selenium deposition in organs, whereas administration of $15 \mathrm{mg} / \mathrm{kg} \mathrm{ZnA}$ was associated with a decrease in these parameters. Thus, the rats from Group II were characterized by a $30 \%$ elevation of muscle selenium levels as compared to the respective control values. At the same time, treatment with 15 $\mathrm{mg} / \mathrm{kg}$ weight $\mathrm{ZnA}$ decreased muscle selenium content by 35 and $55 \%$ as compared to the Group I and II values, respectively. The overall tendency to zinc-induced decrease in muscle selenium levels was significant.

The overall tendency to zinc-associated increase in hair selenium content was not significant after 7 days of treatment. At the same time, administration of 15 $\mathrm{mg} / \mathrm{kg}$ weight zinc asparaginate significantly increased hair selenium content by $13 \%$ as compared to the Group II values. After 2-week treatment the tendency was significant. In particular, hair Se content in rats obtaining $15 \mathrm{mg} / \mathrm{kg}$ zinc asparaginate exceeded the respective values in Group I and II by 18 and $10 \%$.

\section{Correlation between zinc and selenium content in organs and tissues}

In order to specify the association between zinc and selenium in organs and tissues we have performed correlation analysis (Table 2). A significant direct association between $\mathrm{Se}$ and $\mathrm{Zn}$ in liver was observed in animals in both series of experiments. Positive correlation between these metals in kidneys was also observed in rats involved in an experiment for 7 days. Direct association between zinc and selenium content in heart and hair was observed after 14 days of treatment.

\section{The influence of zinc supplementation on serum SOD and GPx activity}

It has been estimated that zinc supplementation significantly affects serum antioxidant enzymes activity (Fig. 1). Despite a 9\% increase in GPx activity in rats obtaining $15 \mathrm{mg} / \mathrm{kg}$ zinc asparaginate for 7 days, the overall tendency was not significant (Fig. 1A). At the same time, Group III values of serum GPx activity were 7 and $8 \%$ higher than the ones obtained for Groups I and II, respectively. The tendency to zinc-induced increase in GPx activity was nearly significant (Fig. 1B). At the same time, intragastric administration of zinc asparaginate did not significantly affect serum SOD activity after 7 (Fig. 1C) and 14 days of experiment (Fig. 1D).

Table 2. Correlation between zinc and selenium content in the studied tissues and organs in rats treated for 7 and 14 days

\begin{tabular}{llcc}
\hline \multicolumn{1}{c}{ Tissue } & \multicolumn{1}{c}{7 days } & \multicolumn{1}{c}{14 days } & General sample \\
\hline Liver & $r=0.566, p=0.028^{*}$ & $r=0.690, p=0.004^{*}$ & $r=0.594, p=0.001^{*}$ \\
Kidney & $r=0.737, p=0.002^{*}$ & $r=-0.299, p=0.280$ & $r=0.271, p=0.148$ \\
Muscle & $r=0.285, p=0.303$ & $r=0.007, p=0.979$ & $r=0.284, p=0.129$ \\
Heart & $r=-0.037, p=0.896$ & $r=0.710, p=0.003^{*}$ & $r=0.217, p=0.250$ \\
Serum & $r=0.020, p=0.943$ & $r=-0.084, p=0.765$ & $r=-0.010, p=0.957$ \\
Hair & $r=-0.023, p=0.929$ & $r=0.636, p=0.005^{*}$ & $r=-0.223, p=0.192$ \\
\hline
\end{tabular}

Data presented as coefficient of correlation $(r)$ and the respective $p$ values.

*Correlation is significant at $p<0.05$. 

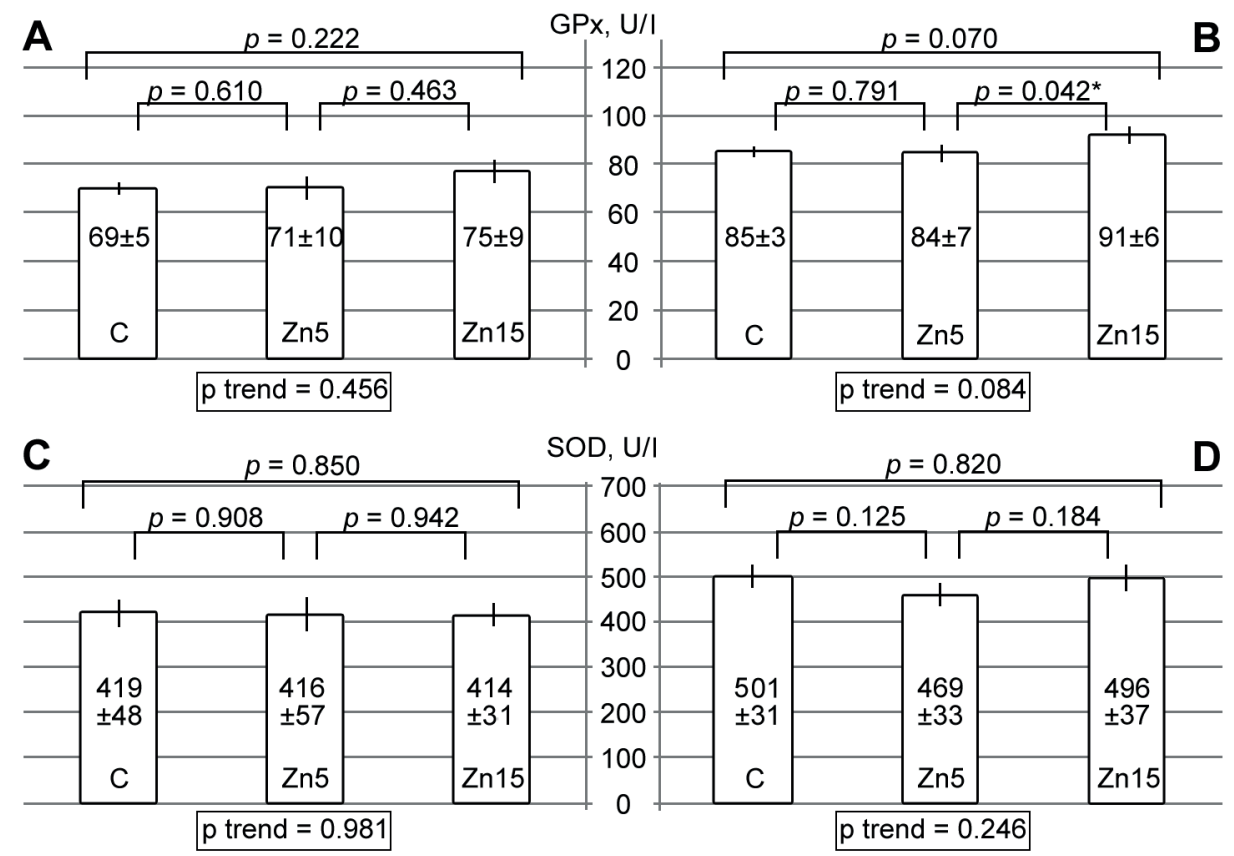

$\mathrm{OD}, \mathrm{U} / \mathrm{I}$

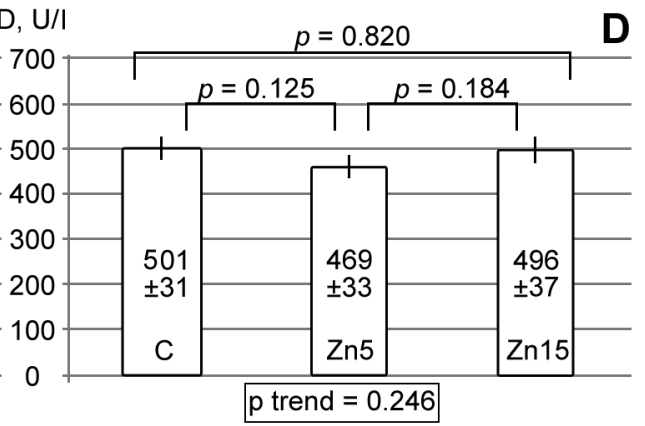

Fig. 1. Effect of zinc supplementation on serum GPx and SOD activity. Graph represents mean values $\pm \mathrm{SD}$ : A - GPx activity in rats after 7-days zinc asparaginate supplementation, B - GPx activity in rats after 14-days zinc asparaginate supplementation, C - SOD activity in rats after 7-days zinc asparaginate supplementation, D - SOD activity in rats after 14-days zinc asparaginate supplementation

Correlation analysis revealed a significant association between serum selenium and GPx activity in rats being treated with zinc both for $7(r=0.651$, $p=0.006)$ and 14 days $(r=0.554, p=0.017)$. At the same time, zinc and selenium concentration in other tissues and organs did not significantly correlate with GPx and SOD activity.

\section{DISCUSSION}

The obtained data indicate a significant influence of intragastric administration of zinc asparaginate on zinc content in various organs and tissues of rats. Total zinc content in the studied organs decreases in the following order: liver $>$ kidney $>$ heart $>$ muscle $>$ serum. These findings are in agreement with previous studies. In particular, it has been shown that administration of zinc oxide nanoparticles results in primary accumulation of zinc in liver as compared to other parenchymatous organs (Baek et al., 2012). Moreover, the obtained data conform to the role of liver as a key organ in zinc homeostasis (Faa et al., 2008).

A dose-dependent increase in serum zinc content also confirms earlier data indicating the effect of oral zinc sulfate supplementation on serum metal concentration in volunteers (Samman and Roberts, 1987).

The observed treatment-induced increase in kidney zinc content is in agreement with previous studies (Chen et al., 1977). It is proposed that such an effect may occur due to a role of kidneys in zinc excretion (Hambidge et al., 1998).

Despite the presence of data indicating the role of muscles as regulatory sites of zinc homeostasis (Krebs et al., 1995), short term zinc administration did not result in significant changes of metal levels in muscles (m. gastrocnemius). Taking into account a short period of treatment, the obtained data indicate that muscle tissue (both myocardium and skeletal muscles) do not play a significant role in homeostatic regulation of zinc balance in acute period of zinc treatment. 
The results of the current study have demonstrated the influence of zinc administration on selenium status in rats. Moreover, the obtained data indicate a positive association between zinc and selenium levels in the organism. This observation is in agreement with the previous study indicating the increase of liver and serum selenium levels in response to zinc treatment (Galażyn-Sidorczuk et al., 2012). At the same time, the exact mechanisms of zinc-induced increase in selenium levels are unknown.

Hypothetically, the influence of zinc on selenium status may occur through modulation of one of the stages of selenium homeostasis: absorption, retention, or excretion. Earlier study has indicated that selenium absorption decreased as the zinc content in the diet increased (House and Welch, 1989). However, zinc administration decreased selenium retention only at higher zinc:selenium ratio (10:1) whereas no antagonism was observed at a 2:1 ratio (Eybl et al., 1986). At the same time, Chmielnicka and the coauthors have demonstrated lower urinary selenium excretion after zinc treatment (Chmielnicka et al., 1988).

The obtained data indicate a positive influence of zinc treatment on serum GPx activity. This observation is in agreement with the earlier study demonstrating an increase in serum zinc and GPx activity in volunteers obtaining zinc supplementation (Kara et al., 2010). The observed direct correlation between serum selenium level and GPx activity confirm earlier data (Luoma et al., 1984; Kim et al., 2011). Such an association is based on the structural role of selenium in GPx molecule (Tappel, 2014). Taking into account a significant association between zinc treatment, serum selenium, and GPx activity, it may be proposed that zinc-induced increase in GPx activity may be mediated through modulation of selenium status. The absence of significant association between zinc levels and serum SOD activity is in agreement with the earlier statement (Bettger, 1993). At the same time, it should be mentioned that only total serum superoxide dismutase activity was analysed in the current investigation, while isolated $\mathrm{Cu}$, $\mathrm{Zn}$-SOD characteristics were not studied. Taking into account the obtained results it proposed that antioxidant action of zinc may be associated with increased GPx but not SOD activity.
Generally, the results of the current study indicate:

1. Intragastric administration of zinc asparaginate significantly increases liver, kidney, and serum zinc content without affecting skeletal and cardiac muscle levels.

2. Zinc supplementation significantly increases selenium retention in the rats' organs. Moreover, a significant positive correlation between zinc and selenium content exists.

3. Zinc asparaginate treatment modulates serum GPx but not SOD activity.

\section{REFERENCES}

Baek, M., Chung, H. E., Yu, J., Lee, J. A., Kim, T. H., Oh, J. M., Lee, W. J., Paek, S. M., Lee, J. K., Jeong, J., Choy, J. H., Choi, S. J. (2012). Pharmacokinetics, tissue distribution, and excretion of zinc oxide nanoparticles. Int. J. Nanomed., 7, 3081-3097.

Barretto, J. R., Silva, L. R., Leite, M. E., Boa-Sorte, N., Pimentel, H., Purificação, A. C., Carvalho, G., Fontes, M. I., Amorim, T. (2008). Poor zinc and selenium status in phenylketonuric children and adolescents in Brazil. Nutr. Res., 28, 3, 208-211.

Bettger, W. J. (1993). Zinc and selenium, site-specific versus general antioxidation. Can. J. Physiol. Pharmacol., 71, 9, 721-724.

Blessing, H., Kraus, S., Heindl, P., Bal, W., Hartwig, A. (2004). Interaction of selenium compounds with zinc finger proteins involved in DNA repair. Eur. J. Biochem., 271, 15, 3190-3199.

Çavdar, A. O., Gözdaşoğlu, S., Babacan, E., Mengübaş, K., Ünal, E., Yavuz, G., Taçyildiz, N. (2009). Zinc and selenium status in pediatric malignant lymphomas. Nutr. Cancer., 61, 6, 888-890.

Chen, R. W., Vasey, E. J., Whanger, P. D. (1977). Accumulation and depletion of zinc in rat liver and kidney metallothionens. J. Nutr., 107, 5, 805-813.

Chmielnicka, J., Zareba, G., Witasik, M., Brzeźnicka, E. (1988). Zinc-selenium interaction in the rat. Biol. Trace Elem. Res., 15, 267-276.

De Jong, N., Gibson, R. S., Thomson, C. D., Ferguson, E. L., McKenzie, J. E., Green, T. J., Horwath, C. C. (2001). Selenium and zinc status are suboptimal in a sample of older New Zealand women in a community - based study. J. Nutr., 131, 10, 2677-2684.

Diplock, A. T. (1993). Indexes of selenium status in human populations. Am. J. Clin. Nutr., 57(2), 256-258. 

term zinc supplementation on zinc and selenium tissue distribution and serum antioxidant enzymes. Acta Sci. Pol. Technol. Aliment., 14(3), 269-276. DOI: 10.17306/J.AFS.2015.3.28

Eybl, V., Sýkora, J., Mertl, F. (1986). In vivo interaction of selenium with zinc. Acta Pharm. Toxicol., 59, 7, $547-548$

Faa, G., Nurchi, V. M., Ravarino, A., Fanni, D., Nemolato, S., Gerosa, C., Van Eyken, P., Geboes, K. (2008). Zinc in gastrointestinal and liver disease. Coord. Chem. Rev., $252,10,1257-1269$.

Fatmi, W., Kechrid, Z., Nazıroğlu, M., Flores-Arce, M. (2013). Selenium supplementation modulates zinc levels and antioxidant values in blood and tissues of diabetic rats fed zinc-deficient diet. Biol. Trace Elem. Res., $152,2,243-250$.

Feroci, G., Badiello, R., Fini, A. (2005). Interactions between different selenium compounds and zinc, cadmium and mercury. J. Trace Elem. Med. Biol., 18, 3, 227-234.

Galażyn-Sidorczuk, M., Brzóska, M. M., Rogalska, J., Roszczenko, A., Jurczuk, M. (2012). Effect of zinc supplementation on glutathione peroxidase activity and selenium concentration in the serum, liver and kidney of rats chronically exposed to cadmium. J. Trace Elem. Med. Biol., 26, 1, 46-52.

Guo, C. H., Chen, P. C., Hsu, G. S., Wang, C. L. (2013). Zinc supplementation alters plasma aluminum and selenium status of patients undergoing dialysis: a pilot study. Nutrients, 5, 4, 1456-1470.

Hambidge, K. M., Krebs, N. F., Miller, L. (1998). Evaluation of zinc metabolism with use of stable-isotope techniques: implications for the assessment of zinc status. Am. J. Clin. Nutr., 68, 2, 410-413.

House, W. A., Welch, R. M. (1989). Bioavailability of and interactions between zinc and selenium in rats fed wheat grain intrinsically labeled with $65 \mathrm{Zn}$ and $75 \mathrm{Se}$. J. Nutr., 119, 6, 916-921.

Kaim, W., Schwederski, B., Klein, A. (2013). Bioinorganic chemistry - inorganic elements in the chemistry of life: An introduction and guide. John Wiley: Chichester.

Kara, E., Gunay, M., Cicioglu, İ., Ozal, M., Kilic, M., Mogulkoc, R., Baltaci, A. K. (2010). Effect of zinc supplementation on antioxidant activity in young wrestlers. Biol. Trace Elem. Res., 134, 1, 55-63.

Khalili, H., Soudbakhsh, A., Hajiabdolbaghi, M., Dashti-Khavidaki, S., Poorzare, A., Saeedi, A. A., Sharififar, R. (2008). Nutritional status and serum zinc and selenium levels in Iranian HIV infected individuals. BMC Infect. Dis., 8, 165.

Kim, H. H., Yang, H. R., Kim, H. Y. P. (2011). Selenium status and glutathione peroxidase activity in Korean infants. Kor. J. Nutr., 44, 2, 112-118.

Krebs, N. F., Miller, L. V., Naake, V. L., Lei, S., Westcott, J. E., Fennessey, P. V., Hambidge, K. M. (1995). The use of stable isotope techniques to assess zinc metabolism. J. Nutr. Biochem., 6, 6, 292-301.

Lee, J. H. (2012). Micronutrient deficiency syndrome: zinc, copper and selenium. Pediatr. Gastroenterol. Hepatol. Nutr., 15(3), 145-150.

Luoma, P. V., Sotaniemi, E. A., Korpela, H., Kumpulainen, J. (1984). Serum selenium, glutathione peroxidase activity and high-density lipoprotein cholesterol - effect of selenium supplementation. Res. Commun. Chem. Pathol. Pharmacol., 46, 3, 469-472.

Prasad, A. S. (2003). Zinc deficiency. BMJ, 326, 7386, 409-410.

Samman, S., Roberts, D. C. (1987). The effect of zinc supplements on plasma zinc and copper levels and the reported symptoms in healthy volunteers. Med. J. Aust., 146, 5, 246-249.

Tappel, A. (2014). Selenium-glutathione peroxidase: properties and synthesis. In M. DeLuca, H. Lardy, R. L. Cross (Eds), Current Topics in Cellular Regulation. Vol. 24. Enzyme Catalysis and Control (pp. 87-96). Orlando, Florida: Academic Press.

Zhao, L. J., Ren, T., Zhong, R. G. (2012). Determination of lead in human hair by high resolution continuum source graphite furnace atomic absorption spectrometry with microwave digestion and solid sampling. Analyt. Lett., $45,2467-2481$.

Accepted for print - Zaakceptowano do druku: 26.06.2015

For citation - Do cytowania

Skalny, A. A., Tinkov, A. A., Medvedeva, Y. S., Alchinova, I. B., Karganov, M. Y., Skalny, A. V., Nikonorov, A. A. (2015). Effect of shortterm zinc supplementation on zinc and selenium tissue distribution and serum antioxidant enzymes. Acta Sci. Pol. Technol. Aliment., 14(3), 269-276. DOI: 10.17306/J.AFS.2015.3.28 